\title{
Patterns of gold levels in urine, serum, and saliva in patients with rheumatoid arthritis undergoing chrysotherapy
}

\author{
M J HEATH, ${ }^{1}$ G T GILLETT, ${ }^{1}$ A J SWANNELL, ${ }^{2}$ C R Williams, ${ }^{3}$ \\ AND T PALMER \\ From the Departments of ${ }^{1}$ Clinical Chemistry and ${ }^{2}$ Rheumatology and Rehabilitation, City Hospital, \\ Nottingham; and the ${ }^{3}$ Department of Life Sciences Trent Polytechnic, Nottingham
}

SUMMARY Twenty patients undergoing treatment with aurothiomalate for rheumatoid arthritis (RA) were studied for the presence of gold in all urine specimens passed over four days and for gold in the serum of blood drawn by venous section at $10.00,16.00$, and 22.00 hours on a single day of the study. Specimens of saliva collected at the same times as the blood specimens were also analysed for (total) gold content. Eighteen patients showed rhythmic urinary gold excretion. Variations were observed in the serum levels for total, free, and protein bound gold at different times of the day and night together with similar variations in the salivary total gold levels. It was established that a possible relation exists between urinary gold, serum gold, and salivary gold such that at times of higher urinary gold excretion the serum gold levels (total, free, and protein bound) and the total salivary gold levels were decreased. Conversely, at times of lower urinary gold excretion serum and salivary gold levels were increased.

Key words: gold therapy, aurothiomalate, circadian rhythms.

The existence of circadian rhythmicity in the urinary excretion of gold in patients with rheumatoid arthritis receiving chrysotherapy has been shown by this group in earlier studies. Circadian variations have been shown for copper in serum by Nielsen ${ }^{2}$ and Munch-Petersen ${ }^{3}$ and for iron by Hoyer, ${ }^{4}$ and therefore a follow up study to our urinary gold work was conducted to examine the possibility of variations in serum levels of gold at different times of day and night and to compare them with urine levels in specimens passed over the same time period. Saliva specimens produced around the times of micturition and venous section were also analysed for gold content. The presence of circadian rhythms in saliva for cortisol has been reported by Price et $a l^{5}$ and for testosterone by Campbell et al. ${ }^{6}$ The prevalence of metallic ions in saliva has been demonstrated by Bauer et al (sodium and potassium), ${ }^{7}$ Kolomaznik et al (lithium), ${ }^{8}$ Tokueva (calcium and inorganic phosphate), ${ }^{9}$ and Nilner and Glantz (copper, silver,

Accepted for publication 18 May 1987.

Correspondence to $\mathrm{Mr} \mathrm{M}$ J Heath, Department of Clinical Chemistry, City Hospital, Hucknall Road, Nottingham NG5 1PB. tin, mercury, and zinc) ${ }^{10}$; hence the possibility of a rhythmic presence of gold was investigated.

\section{Patients and methods}

Twenty new patients with RA receiving gold therapy collected aliquots of all urine specimens passed over four days and noted the times of micturition and the volume of each specimen. On one day of the study each patient collected specimens of saliva around the time of micturition. On the same day each subject had blood withdrawn by venous section at 10.00, 16.00, and 22.00 hours. The urine and saliva specimens were analysed for gold content by atomic absorption spectrophotometry (AA), and the blood specimens were analysed for total, free, and protein bound gold by AA before and after ultrafiltration of the serum. All specimens were analysed in duplicate.

\section{Results}

URIN E

Eighteen of the 20 patients showed rhythmicity in 
urinary gold excretion as demonstrated by histogram and sine wave analysis, in agreement with our earlier studies.

\section{B L O O D}

The 18 subjects showed variations in total gold levels at different times of day. All variations were outside the possible differences due to the coefficient of variation (CV) of the methed (see Table 1). Marked variations in free and protein bound gold were also demonstrated.

\section{S A L I V A}

Gold was detected in all the salivary specimens collected, and variations were observed in these levels at different times of day which were outside the CV of the method. These variations reflected the similar differences observed in the total, free, and protein bound gold levels in serum for blood taken at the same time as the collection of saliva (see Table 1). There was correlation for the group results for total serum gold against salivary gold $(r=0.82$, $\mathrm{p}=0.001$ ), free serum gold against salivary gold $(\mathrm{r}=0 \cdot 70, \mathrm{p}=0 \cdot 001)$, and protein bound gold against salivary gold $(r=0.80, p=0.001)$.

\section{Discussion}

It is evident from the results that each patient studied showed variations in total, free, and protein bound serum gold levels at different times of day and night. Variations in the total salivary gold levels were also shown for specimens collected at the same

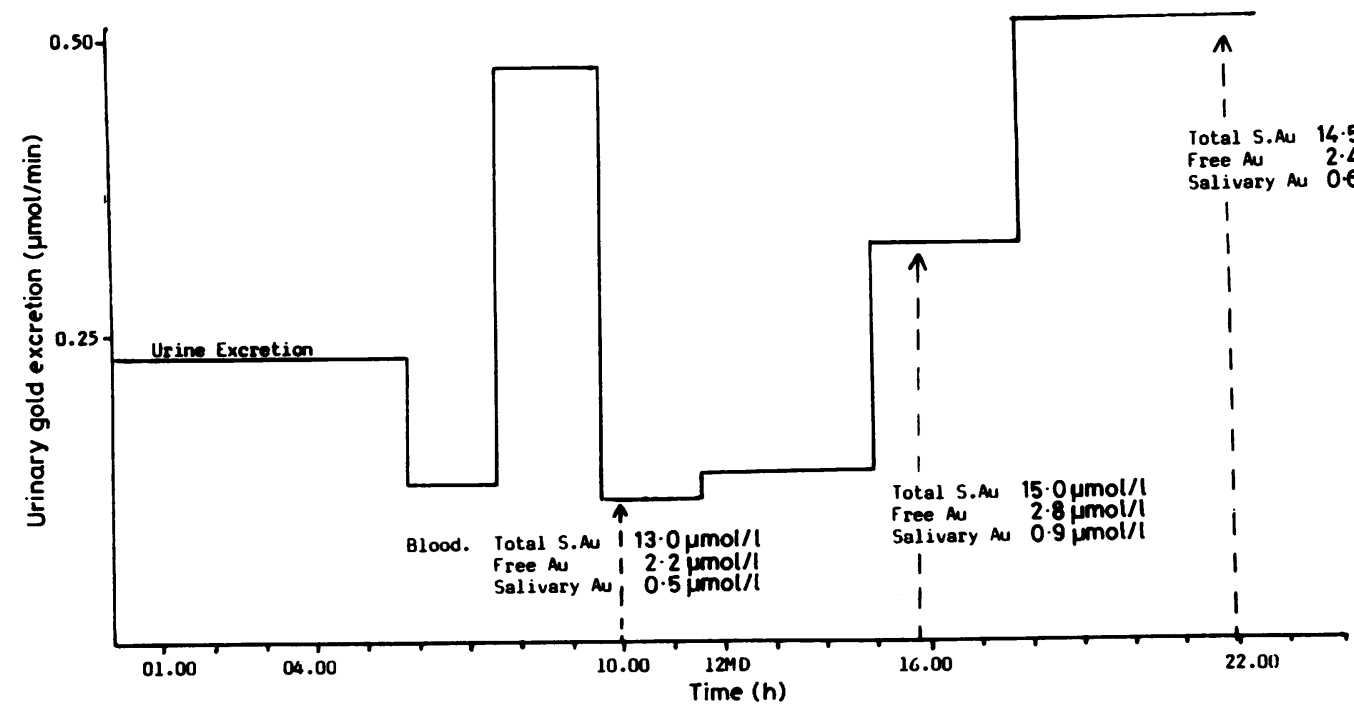

Fig. 1 Urinary gold excretion rates for one day for patient No 3 together with the serum and salivary gold levels that were collected on the same day.
Table 1 Comparison of patients' results at different times of day and night for total serum, free, protein bound, and salivary gold levels together with the relative urinary gold levels

\begin{tabular}{|c|c|c|c|c|c|c|}
\hline $\begin{array}{l}\text { Patient } \\
\text { No }\end{array}$ & Time & $\begin{array}{l}\text { Total } \\
\text { serum } \\
\text { gold } \\
(\mu \mathrm{mol} / \mathrm{l})\end{array}$ & $\begin{array}{l}\text { Free } \\
\text { gold } \\
(\mu \mathrm{mol} / \mathrm{l})\end{array}$ & $\begin{array}{l}\text { Protein } \\
\text { bound } \\
\text { gold } \\
(\mu \mathrm{mol} / \mathrm{l})\end{array}$ & $\begin{array}{l}\text { Salivary } \\
\text { gold } \\
(\mu \mathrm{mol} / \mathrm{l})\end{array}$ & $\begin{array}{l}\text { Relative } \\
\text { urine } \\
\text { gold } \\
\text { levels }\end{array}$ \\
\hline \multirow[t]{3}{*}{1} & $10 \cdot 00$ & 13.0 & $1 \cdot 3$ & $11 \cdot 7$ & 0.5 & Low \\
\hline & 16.00 & $12 \cdot 0$ & $1 \cdot 1$ & $10 \cdot 8$ & $0 \cdot 1$ & High \\
\hline & 22.00 & $13 \cdot 0$ & 1.4 & $11 \cdot 6$ & 0.6 & Low \\
\hline \multirow[t]{3}{*}{2} & $10 \cdot 00$ & $13 \cdot 0$ & 1.9 & $11 \cdot 1$ & $0 \cdot 6$ & High \\
\hline & $16 \cdot 00$ & $15 \cdot 5$ & $2 \cdot 2$ & $13 \cdot 5$ & 0.9 & Low \\
\hline & $22 \cdot 00$ & $14 \cdot 0$ & $2 \cdot 0$ & $11 \cdot 8$ & $0 \cdot 6$ & High \\
\hline \multirow[t]{3}{*}{3} & $10 \cdot 00$ & $13 \cdot 0$ & $2 \cdot 2$ & $10 \cdot 8$ & 0.5 & High \\
\hline & $16 \cdot 00$ & $15 \cdot 0$ & $2 \cdot 8$ & $12 \cdot 3$ & 0.9 & Low \\
\hline & $22 \cdot 00$ & $14 \cdot 5$ & $2 \cdot 4$ & $12 \cdot 2$ & 0.6 & High \\
\hline \multirow[t]{3}{*}{4} & $10 \cdot 00$ & $14 \cdot 5$ & $2 \cdot 4$ & $12 \cdot 1$ & $0 \cdot 6$ & High \\
\hline & $16 \cdot 00$ & $16 \cdot 0$ & 3.0 & $13 \cdot 1$ & $1 \cdot 1$ & Low \\
\hline & $22 \cdot 00$ & $13 \cdot 0$ & $2 \cdot 7$ & $10 \cdot 3$ & 0.7 & High \\
\hline \multirow[t]{3}{*}{5} & $10 \cdot 00$ & $15 \cdot 0$ & $3 \cdot 5$ & $11 \cdot 5$ & 0.6 & Low \\
\hline & $16 \cdot 00$ & $13 \cdot 0$ & $3 \cdot 1$ & 9.9 & 0.4 & High \\
\hline & $22 \cdot 00$ & $15 \cdot 0$ & $3 \cdot 4$ & $11 \cdot 6$ & $0 \cdot 6$ & Low \\
\hline
\end{tabular}

Coefficient of variation (CV) for total gold $1.9 \%$, for free gold $\frac{8}{8} \%$ and for salivary gold $9 \%$.

time as the blood samples. All the variation recorded were outside the possible difference obtainable in results due to the coefficient of variation $(\mathrm{CV})$ of the assay method. Statistica analysis of the results showed a correlation betwee 
total salivary gold. and total serum gold, total salivary gold and free gold, and total salivary gold and protein bound gold. Furthermore, for each patient, at times of higher urinary gold excretion rates total serum gold and its fractions were low, as were salivary gold levels. Conversely, when urine gold levels were low both serum and salivary gold levels were raised (Fig. 1). The urinary excretion of gold has already been shown to be rhythmic, and it is possible that serum and salivary gold level variations are also rhythmic, but it is not possible to establish this conclusively in this study using just three time points in a 24 hour day.

As free serum gold represents the filterable fraction of serum gold by healthy kidneys it is possible that the increase in urine gold may be derived from this serum fraction. There is, however, a decrease in the protein bound level of gold in serum at the same time, which is not filterable, but which might release gold to the depleted free fraction allowing further excretion of gold.

The role of salivary gold in these events is being investigated further by this group by a study of the differential gold fractions in saliva.

\section{References}

1 Heath M J, Swannell A J, Williams C R, Palmer T. Patterns of urinary excretion of gold in patients with rheumatoid arthritis undergoing chrysotherapy. Ann Rheum Dis 1987; 46: 823-6.

2 Nielsen A L. Serum copper. III. Normal values. Acta Med Scand 1944; 118: 87-91.

3 Munch-Petersen $\mathrm{S}$. The variations in serum copper in the course of 24 hours. Scand J Clin Lab Invest 1950; 2: 48-52.

4 Hoyer K. Serumjernets fysiologiske variation. Arhus 1946. (Dissertation.)

5 Price D A. Close G C. Fielding B A. Age of appearance of circadian rhythms in salivary cortisol values in infancy. Arch Dis Child 1983; 58: 454-6.

6 Campbell I T, Walker R F. Riad-Fahmy D, Wilson D W. Circadian rhythms of testosterone and cortisol in saliva: effects of activity-phase shifts and continuous daylight. Chronobiologica 1982; 9: 389-96.

7 Bauer F, Balant L. Zender R. Humair L. Salivary electrolytes and digitalis. Eur Heart $J$ 1983; 4: 64-70.

8 Kolomaznik M, Hronek J, Janonsek I, et al. Contemporary possibilities of assessing lithium in serum from its salivary level. Cesk Psychiatr 1983; 79: 111-7. (English abstract.)

9 Tokueva L I. Mixed salivary calcium and inorganic phosphate, the rate of saliva excretion and caries resistance of the teeth during the mineralisation period in children. Stomatologiia (Mosk) 1983; 62: 62-4. (English abstract.)

10 Nilner K, Glantz P O. The prevalence of copper, silver, tin, mercury and zinc ions in human saliva. Swed Dent J 1982; 6: 71-7. 